\title{
High prevalence of morphological subtype FAB M1 in adults with de novo acute myeloid leukemia in São José dos Campos, São Paulo
}

\author{
Hospital Pio XII, São José dos Campos, São Paulo, Brazil
}

\section{INTREDUCTION}

Geographical heterogeneity of morphological categories defined by the FrenchAmerican-British (FAB) criteria has been demonstrated in acute myelogenous leukemia (AML). High prevalence of FAB M3 subtype has been demonstrated in Brazilian patients. Moreover, there are regions in Brazil such as Campinas (State of São Paulo) and Teresina (State of Piauí) where the most common subtypes are M4 and M2 respectively. FAB M2 has been demonstrated to be the most frequent subtype in Japanese patients and M4 in patients from Australia. ${ }^{1-4}$

The FAB M1 subtype accounts for less than $20 \%$ of the FAB categories and it has been more frequently described in young adults. ${ }^{5}$ In clinical practice, we have noticed an apparently high proportion of AML M1 subtype in older patients in São José dos Campos, State of São Paulo, Brazil.

口BJECTIVE

The aim of this study was to demonstrate the high proportion of morphological FAB M1 subtype in adults with de novo AML in São José dos Campos.

\section{METHDDS}

Type of study: retrospective analysis.

Setting: Patients were isolated in single or double bedrooms at Hospital Pio XII, a public non-teaching hospital in São José dos Campos that provides a full range of medical and surgical services including treatment for hematological malignancy and autologous bone marrow transplantation. AML patients from the $21^{\text {st }}$ Regional Health Division of the State of São Paulo, which is composed of twelve municipalities in the Vale do Paraíba region (over 1,000,000 inhabitants), are referred to Hospital Pio XII.
Sample: Records from 39 consecutive adult patients ( $>18$ years old) with de novo AML attended between January 2002 and September 2004 were reviewed. No one was excluded.

Diagnosis: The diagnosis of de novo AML was confirmed by means of cytological examination of peripheral blood (PB) and bone marrow (BM) and classified according to the $\mathrm{FAB}$ criteria. ${ }^{5} \mathrm{~PB}$ and $\mathrm{BM}$ smears were reviewed blindly by five hematologists. The rate of diagnostic concordance among the observers was $78 \%$. Discrepancies were reviewed once again and each FAB category was determined via a consensus among the five observers.

Chemotherapy: All patients were treated according to the current standard induction regimen. ${ }^{1,2}$

Blood Banking: There was no lack of blood components during the study.

Antimicrobial agents: We followed the 2002 guidelines for the use of antimicrobial agents in neutropenic patients with cancer and there was no lack of antimicrobial agents during the study.

Remission and relapse criteria: Complete remission was defined as M1 marrow status ( $<5 \%$ blasts; $>15 \%$ erythroid elements; and $>25 \%$ normal granulocyte precursors). Relapse was defined as the appearance of circulating leukemia cells or $>5 \%$ blasts in the BM.

Main measurements: The incidence of $\mathrm{FAB}$ categories, the remission rate, the relapse rate, the mortality rate according to treatment phase, the survival rate and the leukemia-free survival rate were measured.

Statistical methods: The survival rate and leukemia-free survival rate were calculated by means of the Kaplan Meier method (SPSS software, SPSS Inc., Chicago, United States).

Consent: This study was authorized by the ethical committee of Hospital Pio XII.
- Fernando Callera

- Carla Cecília Mulin

- Evandro Secchi Rosa

- Dianete Barbosa de Melo

- Cláudio Marcelo Tavares Pessoa de Melo

\section{ABSTRACT}

CONTEXT AND OBJECTIVE: Geographical variations have been described in acute myelogenous leukemia (AML). In Brazil, few studies have been published on this. The aim of this study was to demonstrate the high prevalence of FrenchAmerican-British (FAB) M1 subtype in adults with de novo AML in São José dos Campos, State of São Paulo, Brazil.

DESIGN AND SETTING: Retrospective analysis, at Hospital Pio XII in São José dos Campos, a public non-teaching institution.

METHODS: Records from 39 consecutive adult patients with de novo AML referred to Hospital Pio XII between January 2002 and September 2004 were reviewed. Peripheral blood and blood marrow smears were reviewed blindly by five hematologists and classified according to $F A B$ criteria. The rates of remission, relapse, mortality according treatment phase, survival and leukemia-free survival were calculated.

RESULTS: The prevalence of each category as determined via a consensus among five observers was $\mathrm{M0}: 0 \%$; $\mathrm{Ml}: 43.6 \%$; $\mathrm{M} 2: 30.7 \%$; 33 $12.8 \%$; $M 4: 5.1 \%$; $M 5$ : $2.6 \%$ : $M 6: 2.6 \%$; and M7: $2.6 \%$. The remission and the relapse rates were $82 \%$ and $41 \%$ respectively. The mortality rate was $69 \%$ (induction of remission: $7 / 39$ $17.9 \%$; post induction: $10 / 32,31.2 \%$; and relapse: $10 / 16,62.5 \%$ ). The survival rate was $30 \%$ and leukemia-free survival was $33 \%$.

CONCLUSIONS: The study demonstrated a high prevalence of $F A B M 1$ subtype in adults with de novo AML in São José dos Campos. Our dato suggest the occurrence of different regional prevalences of FAB AML categories in Brazil.

KEY WORDS: Acute myelogenous leukemia Leukemia. Prevalence. Neoplasms. Diagnosis. 
Table 1. Clinical and laboratory characteristics of the 39 patients with de novo acute myelogenous leukemia treated in São José dos Campos between January 2002 and September 2004

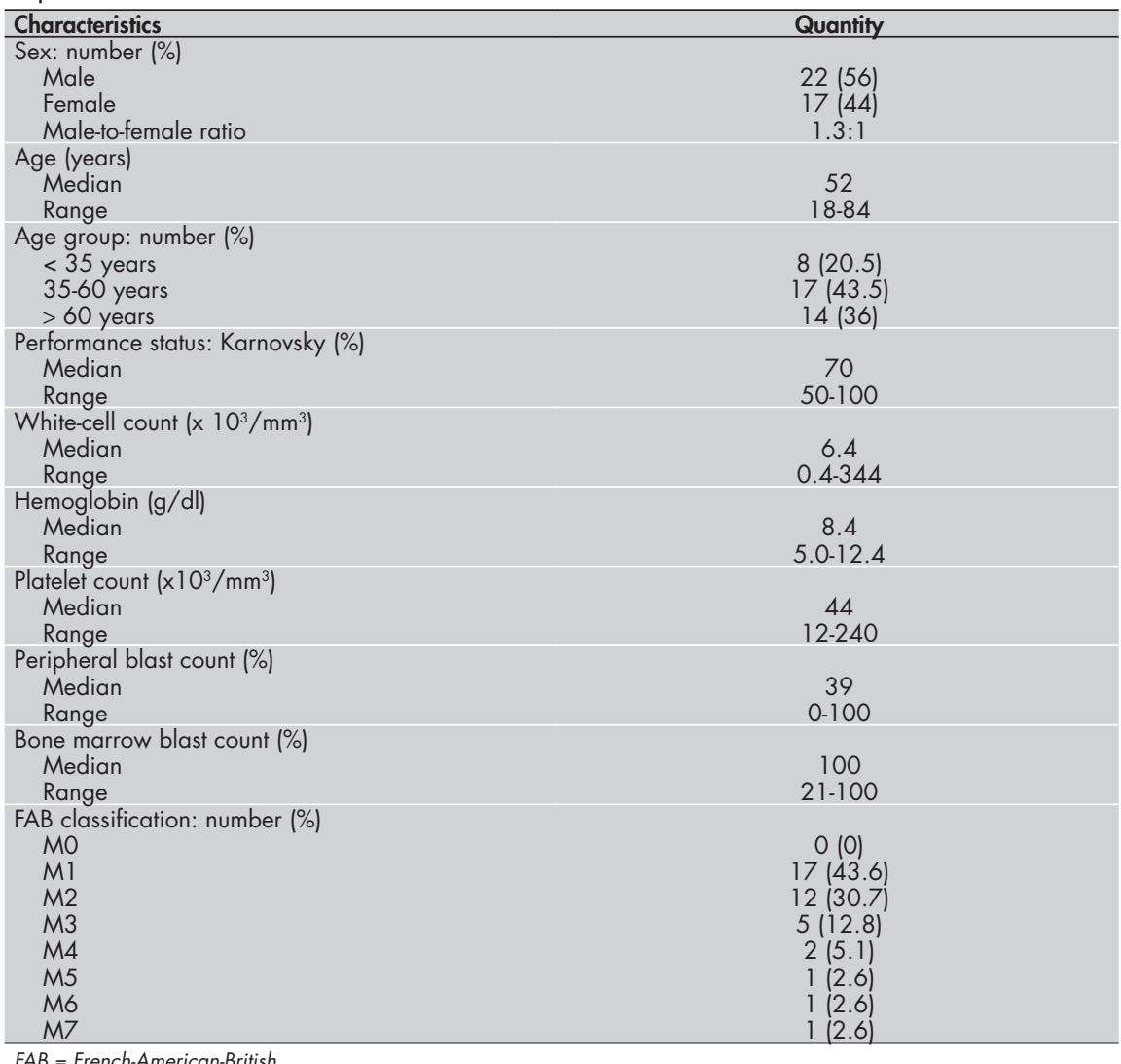

$F A B=$ French-American-British

Table 2. Clinical characteristics of the 27 patients with acute myeloid leukemia, treated in Hospital Pio XII, who died

\begin{tabular}{lc}
\hline Characteristic & Number (\%) \\
\hline Deaths & $18(66.7)$ \\
Male & $9(33.3)$ \\
Female & $27 / 39(69)$ \\
Total & $($ years) \\
Age & 54 \\
Median & $18-84$ \\
Range & \\
Age group & $5 / 8(62.5)$ \\
<35 years & $10 / 17(58.8)$ \\
$35-60$ years & $12 / 14(85.7)$ \\
> 60 years & $7 / 39(17.9)$ \\
Deaths according to the treatment phase or relapse & $10 / 32(31.2)$ \\
Induction of remission & $10 / 16(62.5)$ \\
Post-induction & \\
Relapse & 3 \\
Induction of remission and systems associated with mortality & 2 \\
Respiratory & 2 \\
Hemostatic (disseminated intravascular coagulation) & \\
Nervous (tumor infiltration) & 3 \\
Post-induction and systems associated with mortality & 3 \\
Respiratory/hemostatic (disseminated intravascular coagulation) & 2 \\
Multiple organ failure & 1 \\
Respiratory/cardiovascular & 1 \\
Respiratory/renal & \\
Nervous (tumor infiltration) & \\
Relapse and systems associated with mortality & 4 \\
Multiple organ failure & 3 \\
Respiratory/hemostatic (disseminated intravascular coagulation) & 1 \\
Respiratory/renal & 1 \\
Hemostatic (disseminated intravascular coagulation) & 1 \\
Renal & \\
\hline & \\
\hline
\end{tabular}

RESULTS

The clinical and laboratory characteristics of the 39 patients with AML are shown in Table 1, with predominance $(43.6 \%)$ of M1 FAB classification. Immunophenotyping was performed on 20 patients (51\%), using markers for the clusters of differentiation (CD) CD13 and CD33 and myeloperoxidase-positive markers. There was an association with CD7 in three patients and human leukocyte antigen DR was negative in three patients with FAB M3 subtype. Karyotyping was performed on ten patients (25.6\%); cytogenetic abnormalities were observed in seven: one with normal karyotype, one with complex karyotype, two with $\mathrm{t}(15 ; 17)$, one with $\mathrm{t}(8 ; 21)$ and two with trisomy 8 .

Overall, 32 patients $(82 \%)$ achieved remission; 16 (41\%) relapsed within one year after their diagnosis. Twenty-seven patients (69\%) died and most of them did so within six months after their diagnosis (Table 2). The survival rate was $30 \%$ and the leukemia-free survival rate was $33 \%$.

DISCUSSIDN

The high prevalence of the FAB M1 subtype in this group of patients is not similar to what has previously been described. ${ }^{1-4}$ There are some FAB categories such as M3 AML that are so distinctive that there is a high concordance rate among observers. Problems arise in distinguishing between M1 and M2 and between M2 and M4 AML. Overall, the rates of concordance have varied from 58 to $98 \%$, thus reinforcing the understanding that the accuracy of categorization depends on the skill and experience of the observers. ${ }^{5}$ Therefore, the present cases were reviewed blindly by five hematology morphologists who already had expertise in this field. By using this method we attempted to decrease the element of arbitrariness, decrease the likelihood of misdiagnosis and improve the accuracy of classification. We achieved concordance between all the observers in $78 \%$ of the cases, thus confirming that the categorization of AML subtypes by means of the FAB criteria is reliable and reproducible. It should be noted that agreement was not achieved in the cases of nine patients. The BM smears of these particular cases were reviewed once again. The purpose of this procedure was to improve the classification accuracy and to achieve a consensus among the five observers.

Nonetheless, the high proportion of FAB M1 subtype was based on a sample obtained from a single institution and it should be emphasized that the number of patients studied may be not representative of the entire region. Similar problems 
have been observed in other studies. ${ }^{1,2}$ Considering the incidence rate of new cases of AML in adults in relation to the number of inhabitants in this region (over $1,000,000$ inhabitants) and the period of time studied, a reasonable number of patients were studied. However, further cooperative studies enrolling a greater number of patients would be necessary in order to clarify this point.

Finally, the remission, relapse and mortality rates observed during the induction of remission and during the post-induction period, the survival rate and the leukemia-free survival rate were similar to what has been observed in other regions of Brazil. ${ }^{1-3}$
CDNCLUSIRNS

We have demonstrated that there is high prevalence of the FAB M1 morphological subtype in adults with de novo AML in São José dos Campos. Our data suggest that different prevalences of FAB AML categories occur in different regions of Brazil.

REFERENCES

1. Pulcheri W, Spector N, Nucci M, de Morais JC, Pimenta G, de Oliveira HP. The treatment of acute myeloid leukemia in Brazil: progress and obstacles. Haematologica. 1995;80(2):130-5.

2. Bittencourt R, Fogliato L, Daudt L, et al. Leucemia Mielóide Aguda: perfil de duas décadas do Serviço de Hematologia do Hospital das Clínicas de Porto Alegre - RS. [Acute Myelogenous Leukemia: two decades overview - Hematology Service Hospital de Clínicas de Porto Alegre-RS]. Rev Bras Hematol Hemoter. 2003;25(1):17-24.
3. Rego MF, Pinheiro GS, Metze K, Lorand-Metze I. Acute leukemias in Piauí: comparison with features observed in other regions of Brazil. Braz J Med Biol Res. 2003;36(3):331-7.

4. Nakase K, Bradstock K, Sartor M, et al. Geographic heterogeneity of cellular characteristics of acute myeloid leukemia: a comparative study of Australian and Japanese adult cases. Leukemia. 2000;14(1):163-8.

5. Bain BJ. Acute Leukemia Cytology, Cytochemistry and the FAB
Classification. In: Bain BJ, editor. Leukemia Diagnosis. $2^{\text {nd }} \mathrm{ed}$. Oxford: Blackwell Science; 1999. p. 1-52.

Sources of funding: Serviço de Hematologia e Hemoterapia de São José dos Campos

Conflicts of interest: None

Date of first submission: November 24, 2004

Last received: November 28, 2005

Accepted: November 29, 2005

\section{AUTHOR INFDRMATIDN}

Fernando Callera, MD. Hematology and Hemotherapy Service of São José dos Campos, São Paulo, Brazil.

Carla Cecilia Mulin, MD. Hematology and Hemotherapy Service of São José dos Campos, São Paulo, Brazil.

Evandro Secchi Rosa, MD. Hematology and Hemotherapy Service of São José dos Campos, São Paulo, Brazil.

Djanete Barbosa de Melo, MD. Hematology and Hemotherapy Service of São José dos Campos, São Paulo, Brazil.

Cláudio Marcelo Tavares Pessoa de Melo, MD. Hematology and Hemotherapy Service of São José dos Campos, São Paulo, Brazil.

Address for correspondence:

Fernando Callera

Serviço de Hematologia e Hemoterapia de São José dos Campos

Rua Antonio Sais, 425 - Centro

São José Dos Campos (SP) - Brasil - CEP 12210-040

Tel./Fax. (+55 12) 3921-3766

E-mail: fcallera@shhsic.com.br
Prevalência do subtipo FAB M1 em adultos com leucemia mielóide aguda de novo em São José dos Campos, São Paulo

CONTEXTO E OBJETIVO: Variações geográficas têm sido demonstradas na leucemia mielóide aguda (LMA) No Brasil poucos estudos têm sido publicados nesta área. $O$ objetivo foi demonstrar a alta prevalência do subtipo FAB MI em adultos com LMA de novo em São José dos Campos, São Paulo.

TIPO DE ESTUDO E LOCAL: Análise retrospectiva, no Hospital Pio XII de São José dos Campos, instituição pública e não ligada a universidade.

MÉTODOS: Registros de 39 pacientes consecutivos com LMA de novo foram analisados de janeiro de 2002 até setembro de 2004. Lâminas de sangue periférico e da medula óssea sem identificação prévia foram analisadas por cinco hematologistas e classificadas de acordo com os critérios FAB. Taxas de remissão, de recaída, de mortalidade, de mortalidade de acordo com o período de tratamento, de sobrevivência e de sobrevivência livre de leucemia foram calculadas.

RESULTADOS: A prevalência de cada categoria determinada por consenso entre os observadores foi $\mathrm{MO}$ $0, M 1: 43,6 \%, M 2: 30,7 \%, M 3: 12,8 \%, M 4:-5,1 \%, M 5: 2,6 \%, M 6: 2,6 \%$ and $M 7: 2,6 \%$. As taxas de remissão e de recaída foram de $82 \%$ e $41 \%$ respectivamente. A taxa de mortalidade foi de $69 \%$ (indução da remissão $7 / 39,17.9 \%$, pós-indução 10/32, 31,2\% e de recaída 10/16, 62,5\%). A taxa de sobrevivência foi de $30 \%$ e a taxa de sobrevivência livre de leucemia foi de $33 \%$.

CONCLUSÕES: $\bigcirc$ estudo demonstrou alta prevalência do subtipo FAB MI em adultos com LMA de novo em São José dos Campos. Nossos resultados sugerem a ocorrência de diferentes prevalências de subtipos $\mathrm{FAB}$ nas regiões do Brasil.

PALAVRAS-CHAVE: Leucemia mielocítica aguda. Leucemia. Prevalência. Câncer. Diagnóstico. 